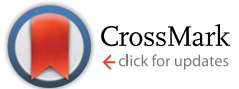

Cite this: Chem. Sci., 2016, 7, 3843

Received 3rd January 2016 Accepted 17th February 2016

DOI: $10.1039 / \mathrm{c} 6 \mathrm{sc} 00015 \mathrm{k}$

www.rsc.org/chemicalscience

\section{Non-cyclic formylated dipyrromethanes as phosphate anion receptors $\uparrow$}

\author{
Murat K. Deliomeroglu, Vincent M. Lynch and Jonathan L. Sessler*
}

New tetrakis- and hexakis( $1 \mathrm{H}$-pyrrole-2-carbaldehyde) anion receptors are described. The anion binding properties of these receptors were studied in organic media and in the solid state. The receptors displayed good affinity for the dihydrogenphosphate and pyrophosphate anions (as the tetrabutylammonium salts) in chloroform even in the presence of a polar protic solvent, methanol. Solution phase spectroscopic analyses proved consistent with the binding mode seen in single crystal structural studies of the dihydrogenphosphate and pyrophosphate complexes and provided support for the contention that these receptors undergo conformational reorganization in order to accommodate the bound oxoanions both in chloroform solution and in the solid state.

\section{Introduction}

Inorganic phosphate and related anions are ubiquitous in nature. These anionic species play key roles in energy transduction and in the storage and expression of genetic information. ${ }^{1}$ Phosphates are also pervasive pollutants and may lead to eutrophication of lakes and waterways. ${ }^{2}$ The development of molecular constructs capable of binding the phosphate anion in its various protonated forms, as well as related oxoanion species is of critical interest since it may provide a first step towards solving various problems related to anion detection, extraction, and separation..$^{3-6}$ In general, anions are larger than cations and therefore larger hosts are required to bind them. ${ }^{7}$ Fortunately, a number of binding motifs may be exploited to achieve anion recognition, including coulombic interactions, hydrogen bonding, halogen bonding, and anion- $\pi$ interactions. ${ }^{8-12}$ Hydrogen bonding has proven particularly effective. However, certain anions, including oxoanions, such as dihydrogenphosphate $\left(\mathrm{H}_{2} \mathrm{PO}_{4}{ }^{-}\right)$and hydrogensulfate $\left(\mathrm{HSO}_{4}{ }^{-}\right)$, are susceptible to proton transfer. ${ }^{13}$ As a result, ensuring anion binding rather than deprotonation (acid-base chemistry) has proven to be a challenging task. ${ }^{\mathbf{1 4 , 1 5}}$ One hydrogen bond donor that is relatively less susceptible to deprotonation is pyrrole. An early example of a pyrrole-based system capable of binding the phosphate anion was the pentapyrrolic macrocycle, sapphyrin. This system, which is dicationic in its protonated form, proved capable of stabilizing a "sitting-atop" complex with the phosphate anion in the solid state and of binding DNA and other

Department of Chemistry, The University of Texas at Austin, Texas 78712-1224, USA. E-mail: Sessler@cm.utexas.edu

$\dagger$ Electronic supplementary information (ESI) available: Synthetic details, NMR and UV-Vis spectroscopic data, electrochemical analyses, and X-ray diffraction data. CCDC 1444557-1444561. For ESI and crystallographic data in CIF or other electronic format see DOI: $10.1039 / \mathrm{c} 6 \mathrm{sc} 00015 \mathrm{k}$ phosphate-containing species in solution. ${ }^{\mathbf{1 6}}$ In 1996, Gale et al. reported that octamethylcalix[4]pyrrole $(\mathrm{C}[4] \mathrm{P} ; \mathbf{1})$ may act as an anion receptor in organic media. ${ }^{17}$ Calix[4]pyrrole is a nonconjugated system long known in the literature. ${ }^{18}$ It was found to bind the fluoride and chloride anions in halogenated solvents, along with their counter cations in some cases. ${ }^{\mathbf{1 9 , 2 0}}$ Halide anion recognition by $\mathrm{C}[4] \mathrm{P}$ is accompanied by conformational change from a limiting 1,3-alternate conformation (the free form) to a cone conformation (halide-bonded form). This structural switching allows the formation of four $\mathrm{NH}-$ anion hydrogen bonds in the case of simple halide anions. ${ }^{17}$ Under most experimental conditions, $\mathrm{C}[4] \mathrm{P}$ has proved less effective as a receptor for larger anions, including the dihydrogenphosphate anion. There thus remains a need for simpleto-prepare analogues of $\mathrm{C}[4] \mathrm{P}$ that bind phosphate. Open-chain systems might allow this goal to be attained (Scheme 1).

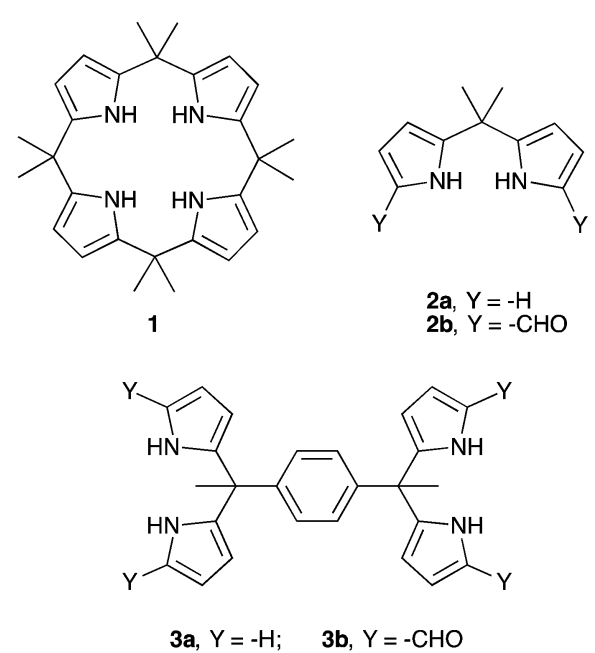

Scheme 1 Structures of compounds 1, 2a-b, and 3a-b. 
In the case of fluoride and chloride anion salts studied in organic media, compound 1 displayed association constants that were $>2 \times$ greater than those recorded for the corresponding acyclic building block, dipyrromethane (DPM) 2a. ${ }^{21}$ This difference was ascribed to the greater pre-organization of the cyclic systems, as well as to the increased number of pyrrolic $\mathrm{NH}$ hydrogen bond donors provided by 1 compared to $2 \mathbf{2}$. Interestingly, compound 2a displayed a higher affinity towards $\mathrm{H}_{2} \mathrm{PO}_{4}{ }^{-}$(as its tetra- $n$-butylammonium (TBA ${ }^{+}$) salt) than did 1 in $\mathrm{CD}_{2} \mathrm{Cl}_{2}$. While this apparent dichotomy was not studied in detail, it might reflect the fact that the dihydrogenphosphate anion is too large to be accommodated well within the NH-rich calix[4]pyrrole pseudo cavity. In contrast, the presumably greater flexibility of $2 \mathrm{a}$ might allow the stabilization of a greater number of favourable contacts with this and other oxoanions than compound $\mathbf{1}$. While untested, this hypothesis provides an incentive to prepare and study new dipyrromethane-based anion receptors. A goal of this effort would be to create phosphate anion receptors that rival $\mathrm{C}[4] \mathrm{P}$ in terms of ease of preparation and which allow for good phosphate anion binding. In this study we focus on dipyrromethane (DPM) receptors that have been subject to formylation in the so-called $\alpha$-pyrrolic positions.

In 2003, in the context of synthetic work aimed at producing a C[4]P-texaphyrin chimera, ${ }^{22}$ the pyrrolic $\alpha$-positions of 2 a were subject to formylation to produce $2 \mathbf{b}$. The anion binding properties of $\mathbf{2 b}$ with TBAF were studied by isothermal calorimetry (ITC) in acetonitrile and via X-ray crystallography in the solid state. ${ }^{23}$ On this basis, it was concluded that $\mathbf{2 b}$ was not an effective anion receptor. On the other hand, we recently found ${ }^{24}$ that the bisdipyyrromethane (bisDPM) 3a and its formylated derivative $\mathbf{3 b}$, act as effective and somewhat selective receptors for the $\mathrm{TBA}^{+}$salts of dihydrogenphosphate $\left(\mathrm{H}_{2} \mathrm{PO}_{4}{ }^{-}\right)$and hydrogenpyrophosphate $\left(\mathrm{HP}_{2} \mathrm{O}_{7}{ }^{3-}\right)$ in chloroform, as inferred from NMR spectroscopic and UV-Vis analyses. As compared to 1, the non-formylated system 3a proved to be a slightly better receptor for $\mathrm{H}_{2} \mathrm{PO}_{4}{ }^{-}\left(K_{\mathrm{a}}=10^{3}\right.$ vs. $10^{2} \mathrm{M}^{-1}$ in $\mathrm{CHCl}_{3}$ and $\mathrm{CH}_{2} \mathrm{Cl}_{2}$, respectively). DPM derivatives, which do not bear substituents in the pyrrolic $\alpha$-positions are notoriously unstable, being prone inter alia to oxidative coupling and electrophilic aromatic substitution. On the other hand, bis-formylation yields stable systems that we believe may have a role to play as anion receptors. In preliminary work, high phosphate anion affinities were noted for the four-fold formylated derivative of 3a, receptor $3 \mathbf{b}\left(K_{\mathrm{a}}=(8 \pm 2) \times 10^{6} \mathrm{M}^{-1}\right.$ for $3 \mathbf{b} v s .(1.0 \pm 0.1) \times 10^{3} \mathrm{M}^{-1}$ for $3 \mathbf{a}$ in $\mathrm{CHCl}_{3}$; cf. Table 1). ${ }^{24}$ Presumably, this increased affinity reflects the favourable electronic changes, as well as the

Table 1 Calculated $\mathrm{H}_{2} \mathrm{PO}_{4}{ }^{-}$binding affinities, $K_{\mathrm{a}}\left(\mathrm{M}^{-1}\right)$ of dipyrromethane derivatives before ( $3 a$ and $5 a$ ) and after formylation ( $3 b$ and 5b)

\begin{tabular}{llll}
\hline $\mathbf{3 \mathbf { a } ^ { a , c }}$ & $\mathbf{3 \mathbf { b } ^ { b , c }}$ & $\mathbf{5 \mathbf { a } ^ { a }}$ & $\mathbf{5 \mathbf { b } ^ { b , c }}$ \\
\hline$(1.0 \pm 0.1) \times 10^{3}$ & $(8 \pm 2) \times 10^{6}$ & $40.8 \pm 0.6$ & $(4.6 \pm 0.9) \times 10^{5}$
\end{tabular}

${ }^{a}$ Determined using ${ }^{1} \mathrm{H}$ NMR spectroscopy in $\mathrm{CDCl}_{3} \cdot{ }^{b}$ Determined using UV-Vis spectroscopy in $\mathrm{CHCl}_{3} .{ }^{c}$ Values from ref. 24. addition of hydrogen bond accepting sites, that result from formylation. To understand the underlying determinants and to improve on the phosphate binding affinity displayed by $\mathbf{3} \mathbf{b}$, we have now prepared and studied several analogues bearing different spacer elements between the diformyl-DPM subunits, as well as a new hexakis(1H-pyrrole-2-carbaldehyde) receptor, $\mathbf{7 b}$. Compared to $\mathbf{3 b}$, receptor $\mathbf{7 b}$ displays a phosphate anion affinity that is enhanced by roughly 66 fold when studied under identical conditions (i.e., $\mathrm{CHCl}_{3}$ containing $3 \% \mathrm{CH}_{3} \mathrm{OH}$ ).

\section{Results and discussion}

\section{Syntheses and single crystal structures}

The synthesis and characterization of $\mathbf{3 b} \mathbf{- 5} \mathbf{5}$ have been reported previously. ${ }^{24}$ In this paper, we present the new derivatives, $6 \mathbf{b}$ and $7 \mathbf{b}$, obtained in moderate overall yields. The synthetic route to obtain $\mathbf{3 b}-\mathbf{7 b}$ is shown in Scheme 2. In the first step, commercially available diacetyl and triacetyl starting materials were converted into bisDPM 6a, and trisdipyrromethane (trisDPM) 7a, respectively, albeit in low yields (5-15\%). The low yields stand in contrast to high yields observed for $\mathbf{3 a}$ and $\mathbf{5 a}$, which precipitate from the reaction mixture and constitute the dominant reaction products. ${ }^{24}$ The unstable $\alpha$-free bisDPM (6a) and trisDPM (7a) were then subject to Vilsmeier-Haack formylation to produce the stable formylated products $\mathbf{6 b}$ and $\mathbf{7 b}$ in relatively high yields ( $c a$. 80\%). Purification of $\mathbf{6 b}$ was carried out by recrystallization from $N, N$-dimethylformamide (DMF) at $80^{\circ} \mathrm{C}$, whereas $7 \mathbf{b}$ was purified by column chromatography over

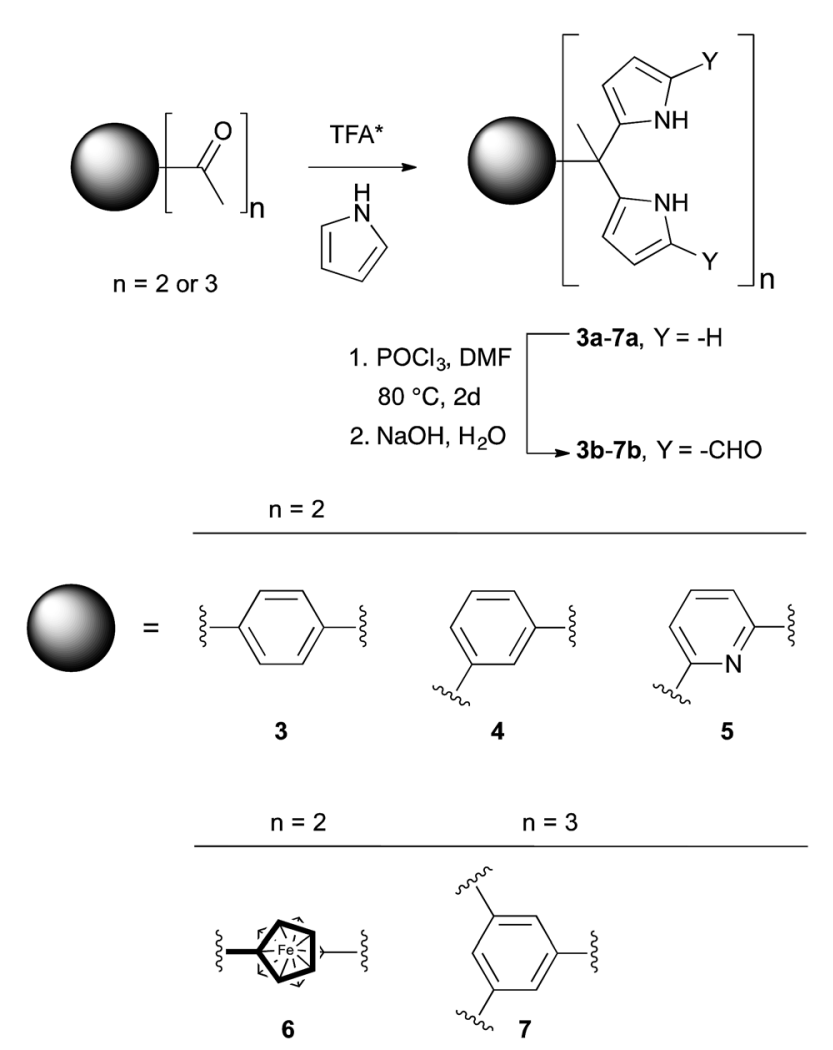

Scheme 2 Synthesis of receptors $3 b-7 b$. *Catalyst concentrations and reaction temperatures vary. 
silica gel. The molecular structures were characterized by ${ }^{1} \mathrm{H}$ and ${ }^{13} \mathrm{C}$ NMR spectroscopy, high-resolution mass spectrometry (HRMS), and single crystal X-ray diffraction analyses.

Receptor $\mathbf{6 b}$ co-crystallised with two molecules of DMF. The single crystal structure revealed that two diformyl-DPM units residing on opposite cyclopentadienyl $(\mathrm{Cp})$ rings of the ferrocene were locked at about $90^{\circ}$ from one another, leading to the presence of a racemic mixture of conformational isomers within the single crystal. Fig. 1 shows one of the atropisomers of $\mathbf{6 b}$. It crystallizes as a one-dimensional hydrogen bond interlocked ensemble, even in the presence of DMF. The formation of these assemblies can be rationalized on a geometric basis. The bridging ferrocene adopts a conformation such that the two constituent $\mathrm{Cp}$ rings, each bearing a DPM substituent, are offset from one another by $90^{\circ}$. This allows for the formation of four intermolecular hydrogen bonds between the two self-complementary diformylDPM subunits, as can be seen from an inspection of Fig. 1.

Receptor $\mathbf{7 b}$, on the other hand, co-crystallised with $\mathrm{CHCl}_{3}$. Each of the three diformyl-DPM units on the bridging benzene is oriented in a different direction ( $c f$. Fig. 1). One of the three DPM subunits was found to resemble what is seen in the case of $\mathbf{3} \mathbf{b}^{\mathbf{2 4}}$ wherein two diformyl-DPM units are seen to orient towards opposite $\pi$-faces of the intervening benzene ring. On the other hand, two of the diformyl-DPM units present in $\mathbf{7 b}$ adopt conformations in which the pyrrole $\mathrm{NH}$ groups point away from one another. As a result, $\mathbf{7 b}$ forms dimers stabilised by four hydrogen bonds that extend to create two-dimensional layers (cf. Fig. S2 $\dagger$ ). The assemblies formed by $\mathbf{6 b}$ and $\mathbf{7 b}$ may be viewed as being examples of Gale and co-worker's "narcissistic dimer"15 that are extended into one and two-dimensional space, respectively. The hydrogen bond interlocked aggregates seen in the solid state structures of $\mathbf{6 b}$ and $\mathbf{7 b}$ may account for the low solubility these species display in many solvents.

\section{Anion binding studies}

The anion selectivity for $\mathbf{3 b} \mathbf{- 5} \mathbf{b}$ in $\mathrm{CHCl}_{3}$ was found to be $\mathrm{H}_{2} \mathrm{PO}_{4}{ }^{-}>\mathrm{HP}_{2} \mathrm{O}_{7}{ }^{3-}>\mathrm{HSO}_{4}{ }^{-}>\mathrm{C}_{6} \mathrm{H}_{5} \mathrm{CO}_{2}{ }^{-} \gg \mathrm{NO}_{3}{ }^{-}, \mathrm{Cl}^{-}$(as the
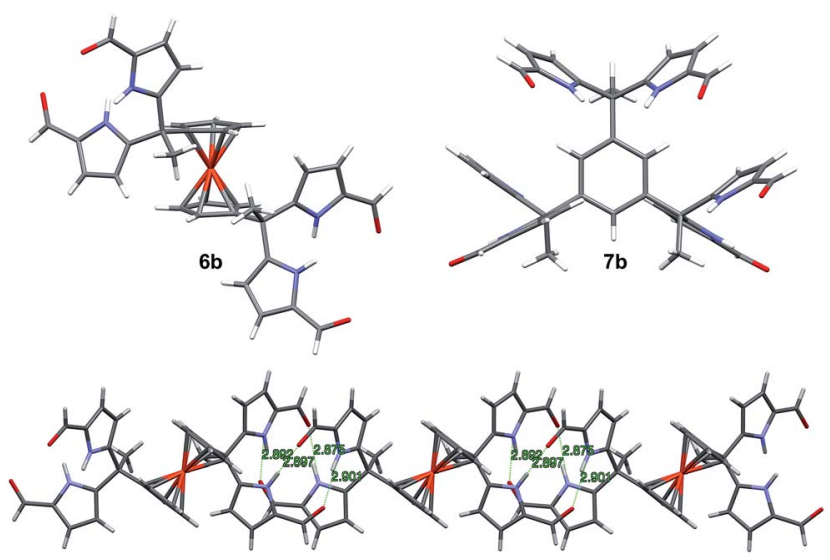

Fig. 1 Top left: Single crystal structure of $6 b$ (DMF solvent molecules are omitted for clarity); Top right: Single crystal structure of $7 \mathrm{~b}\left(\mathrm{CHCl}_{3}\right.$ solvent molecules are omitted for clarity); Bottom: Linear assembly formed by one of the atropisomers of $6 b$. commercially available $\mathrm{TBA}^{+}$salts). ${ }^{24}$ The observed selectivity was not found to correlate with the basicity of the anions (basicity order: $\mathrm{HP}_{2} \mathrm{O}_{7}{ }^{3-}>\mathrm{C}_{6} \mathrm{H}_{5} \mathrm{CO}_{2}{ }^{-}>\mathrm{H}_{2} \mathrm{PO}_{4}{ }^{-}>\mathrm{HSO}_{4}{ }^{-}, \mathrm{NO}_{3}{ }^{-}$, $\mathrm{Cl}^{-}$). Rather, the trend appears to correlate with an ability of the anion to interact with the receptor via hydrogen bond donation to the formyl groups (in addition to acting as a Lewis basic hydrogen bond acceptor for the pyrrolic NH protons). In fact, the $\mathrm{H}_{2} \mathrm{PO}_{4}{ }^{-}$anion, with two hydrogen bond donating sites (rather than one or none as in the other test anions), is bound with the highest relative affinity.

The effect of the formyl groups in abetting dihydrogenphosphate anion binding is substantial (i.e., several orders of magnitude difference in $K_{\mathrm{a}}$ values). This was first noted for $3 \mathbf{a} v s$. $\mathbf{3} \mathbf{b}$ in the context of our original report (vide supra). ${ }^{24}$ Further support for this conclusion came from a comparison of the $\alpha$-free derivative $\mathbf{5 a}$ with its formylated congener 5b ( $c f$. Table 1). Unfortunately, the other non-formylated DPM derivatives prepared in the context of this study proved too unstable to allow for analyses of their anion binding affinities.

Diffusion ordered NMR spectroscopy (DOSY) ${ }^{25}$ was used to examine the interactions between anions and receptor $\mathbf{3 b}$. Receptor $\mathbf{3 b}$ was chosen for these studies for two reasons. First,

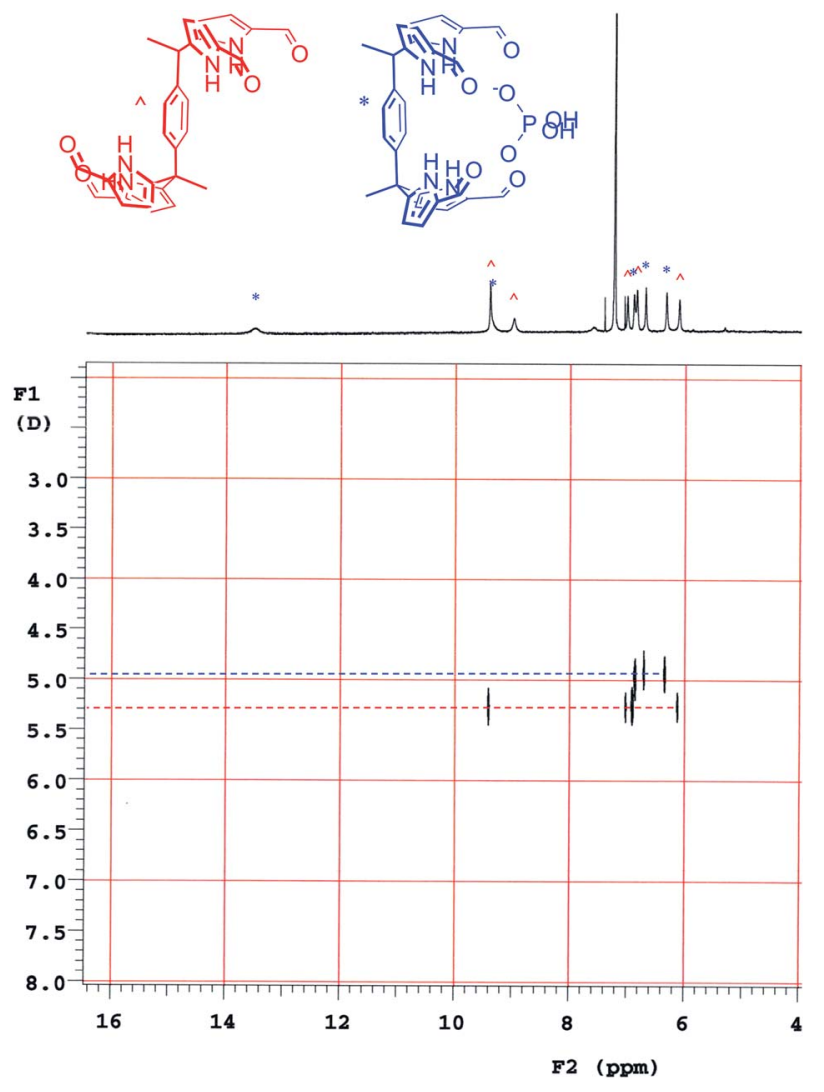

Fig. 2 DOSY spectrum of a $1: 0.5$ mixture of $3 \mathrm{~b}$ and $\mathrm{TBAH}_{2} \mathrm{PO}_{4}$. The mixture was produced by titrating a $0.8 \mathrm{mM} \mathrm{CDCl}_{3}$ solution of $\mathrm{TBAH}_{2} \mathrm{PO}_{4}$ into a turbid mixture of $3 \mathrm{~b}$ in $\mathrm{CDCl}_{3}$ until the ratio of integration values corresponding to $3 \mathrm{~b}$ and $3 \mathrm{~b} \cdot \mathrm{H}_{2} \mathrm{PO}_{4}{ }^{-}$was equal. $\wedge$ shows signals ascribed to free $3 \mathrm{~b} ; *$ shows those assigned to $3 b \cdot \mathrm{H}_{2} \mathrm{PO}_{4}^{-}$. 
the low solubility of $\mathbf{3 b}$ in $\mathrm{CHCl}_{3}$ means that an equilibrium was expected to exist between species free in solution and those tied up in the solid state. Secondly, on the ${ }^{1} \mathrm{H}$ NMR time scale, free receptor $3 \mathbf{b}$ and the $\mathrm{H}_{2} \mathrm{PO}_{4}{ }^{-}$bound complex $\left(3 \mathbf{b} \cdot \mathrm{H}_{2} \mathrm{PO}_{4}{ }^{-}\right)$were subject to slow-exchange, ${ }^{24}$ allowing both species to be observed concurrently. Fig. 2 shows the DOSY spectrum of a mixture of $\mathbf{3 b}$ at the half-equivalence point obtained by titrating $\mathbf{3 b}$ with $\mathrm{TBAH}_{2} \mathrm{PO}_{4}$ in $\mathrm{CDCl}_{3}$. The one-dimensional ${ }^{1} \mathrm{H}$ NMR spectrum in the horizontal axis shows two sets of receptor signals; free $\mathbf{3 b}$ and $3 \mathbf{b} \cdot \mathrm{H}_{2} \mathrm{PO}_{4}{ }^{-}$, labelled with red and blue asterisks, respectively.

The two-dimensional spectrum is characterized by the presence of two sets of receptor signals corresponding to slightly different diffusion rates. The complex $3 \mathbf{b} \cdot \mathrm{H}_{2} \mathrm{PO}_{4}{ }^{-}$(blue) features a lower mobility than the free receptor $\mathbf{3 b}$ (red). No evidence of higher order (i.e., aggregated) species is seen. Based on these observations, we conclude that in the absence of complete conversion to the bound form, samples of $\mathbf{3} \mathbf{b}$ and $\mathrm{TBAH}_{2} \mathrm{PO}_{4}$ consist of only two receptor species, namely the free form and the bound complex, $3 \mathbf{b} \cdot \mathrm{H}_{2} \mathrm{PO}_{4}{ }^{-}$. Support for the existence of two components in solution came from a UV-Vis study, ${ }^{24}$ also carried out in $\mathrm{CHCl}_{3}$. When the total concentration of $\mathbf{3 b}$ was held constant, isosbestic behaviour was seen upon titration with $\mathrm{TBAH}_{2} \mathrm{PO}_{4}$. This is as expected for a receptor solution consisting of two interconverting species. ${ }^{24}$

Mass spectrometric (MS) analyses provided evidence that receptor $3 \mathbf{b}$ would interact with the $\mathrm{H}_{2} \mathrm{PO}_{4}{ }^{-}$anion in the gas phase. In these studies, an equimolar mixture of $\mathbf{3 b}$ and $\mathrm{TBAH}_{2} \mathrm{PO}_{4}$ in $\mathrm{CHCl}_{3}$ was directly injected into the MS instrument without passing the species through a column. Negative ion electrospray ionization $\left(\mathrm{ESI}^{-}\right)$was used. The high-resolution MS analysis revealed two expected signals, namely, one at $\mathrm{m} / \mathrm{z}$ 505.1885 corresponding to $[3 \mathbf{b}-\mathrm{H}]^{-}$and one at $\mathrm{m} / \mathrm{z} 603.1643$ ascribable to the $\mathrm{H}_{2} \mathrm{PO}_{4}{ }^{-}$complex $\left(\left[3 \mathbf{b} \cdot \mathrm{H}_{2} \mathrm{PO}_{4}{ }^{-}\right]\right)$. ( $c f$. Fig. $\left.\mathrm{S} 4 \dagger\right)$.

Further insights into the binding modes operative in the case of the present series of receptors came from single crystal X-ray diffraction analyses. ${ }^{26}$ Diffraction-grade single crystals of

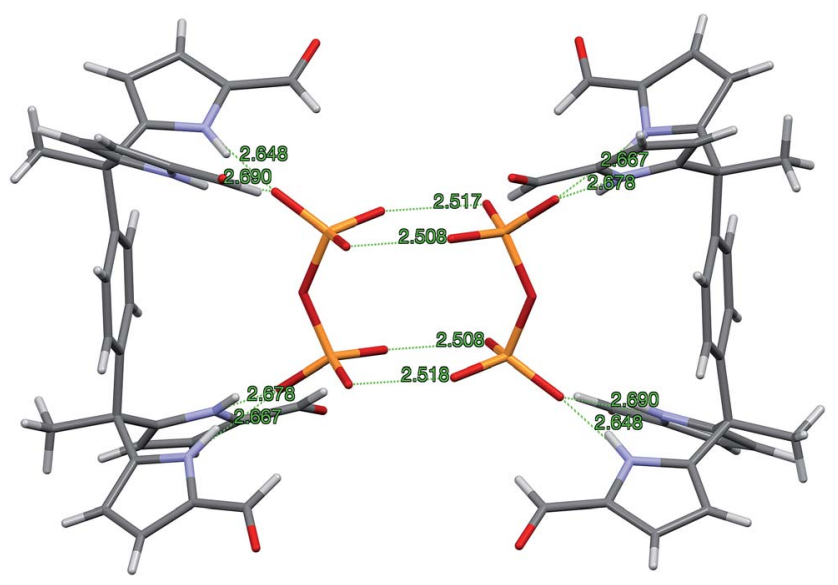

Fig. 3 Single crystal structure of the $2: 2$ complex $\left[3 \mathrm{~b} \cdot \mathrm{H}_{2} \mathrm{P}_{2} \mathrm{O}_{7}{ }^{2-}\right]_{2}$ viewed from the side relative to the bridging benzene rings. Two TBA counter cations and the disordered $\mathrm{CH}_{2} \mathrm{Cl}_{2}$ solvent molecules per pyrophosphate are omitted for clarity. the pyrophosphate complex, $3 \mathbf{b} \cdot(\mathrm{TBA})_{2} \mathrm{H}_{2} \mathrm{P}_{2} \mathrm{O}_{7}$, were obtained by layering a solution of $3 \mathbf{b} \cdot \mathrm{H}_{2} \mathrm{P}_{2} \mathrm{O}_{7}^{2-}$ in $\mathrm{CH}_{2} \mathrm{Cl}_{2}$ with $n$-pentane. The complex $3 \mathbf{b} \cdot \mathrm{H}_{2} \mathrm{P}_{2} \mathrm{O}_{7}{ }^{2-}$ in $\mathrm{CH}_{2} \mathrm{Cl}_{2}$ was prepared by treating $3 \mathbf{b}$ with (TBA) $)_{3} \mathrm{HP}_{2} \mathrm{O}_{7}$. This served to improve the net solubility by converting the poorly soluble receptor (vide supra) to the corresponding pyrophosphate complex. In the solid state, a $2: 2$ complex, $\left[3 \mathbf{b} \cdot \mathrm{H}_{2} \mathrm{P}_{2} \mathrm{O}_{7}{ }^{2-}\right]_{2}$ is seen. The overall complex consists of a hydrogen-bonded dimer that lies across a crystallographic inversion centre ( $c f$. Fig. 3).

The protonation state of the bound pyrophosphate in the complex $\left[3 \mathbf{b} \cdot \mathrm{H}_{2} \mathrm{P}_{2} \mathrm{O}_{7}{ }^{2-}\right]_{2}$ was deduced from the presence of two $\mathrm{TBA}^{+}$counter cations per pyrophosphate dianion. The $\mathrm{H}_{2} \mathrm{P}_{2} \mathrm{O}_{7}{ }^{2-}$ anion lies parallel to the $\pi$-surface of the bridging benzene ring. Both diformyl-DPM arms are oriented such that four hydrogen bonds between the diformyl-DPM units in $\mathbf{3 b}$ and the bound $\mathrm{H}_{2} \mathrm{P}_{2} \mathrm{O}_{7}{ }^{2-}$ are favoured. The $\mathrm{N}-\mathrm{H} \cdots \mathrm{O}$ distances between the $\mathrm{NH}$ protons of $3 \mathbf{b}$ and the $\mathrm{O}$ atoms of $\mathrm{H}_{2} \mathrm{P}_{2} \mathrm{O}_{7}{ }^{2-}$ range from 2.648 to $2.690 \AA$, separations that are short compared to typical $\mathrm{N}-\mathrm{H} \cdots \mathrm{O}$ distances. ${ }^{27,28}$ Each bound $\mathrm{H}_{2} \mathrm{P}_{2} \mathrm{O}_{7}{ }^{2-}$ interacts with another pyrophosphate anion with the result that a hydrogen bonded dimer is formed. In the dimer, four protons are shared between eight oxygen atoms. The observed $\mathrm{O} \cdots \mathrm{O}$ distances of $2.508-$ $2.518 \AA$ are within the range expected for this type of proton bridged $\mathrm{O}-\mathrm{H} \cdots \mathrm{O}$ type interaction. ${ }^{28-30}$ Because the hydrogen atoms on $\mathrm{H}_{2} \mathrm{P}_{2} \mathrm{O}_{7}{ }^{2-}$ are involved in dimer formation, the formyl groups do not participate in the hydrogen bonds that serve to bind the anion. Indeed, the formyl groups point away from the bound $\mathrm{H}_{2} \mathrm{P}_{2} \mathrm{O}_{7}{ }^{2-}$ guest.

Diffraction grade single crystals of the complex $\mathbf{4 b} \cdot \mathrm{TBAH}_{2}-$ $\mathrm{PO}_{4}$ were obtained in a similar way. The resulting structure is shown in Fig. 4. There is no evidence of dimerization in this case. The lack of dimerization is ascribed to the relatively tight binding between the $\mathrm{TBA}^{+}$counter cation and the bound dihydrogenphosphate guest, which precludes further inter-complex interactions. In the solid state, complex $4 \mathbf{b} \cdot \mathrm{H}_{2} \mathrm{PO}_{4}{ }^{-}$displays the same conformation for the diformyl-DPM units as observed in $3 \mathbf{b} \cdot \mathrm{H}_{2} \mathrm{P}_{2} \mathrm{O}_{7}{ }^{2-}$. The four $\mathrm{N}-\mathrm{H} \cdots \mathrm{O}$ distances that characterize the interaction between the $\mathrm{NH}$ protons of $\mathbf{4 b}$ and the $\mathrm{O}$ atoms of $\mathrm{H}_{2} \mathrm{PO}_{4}{ }^{-}$range from 2.704 to $2.760 \AA$. The two $\mathrm{O}-\mathrm{H} \cdots \mathrm{O}$ distances

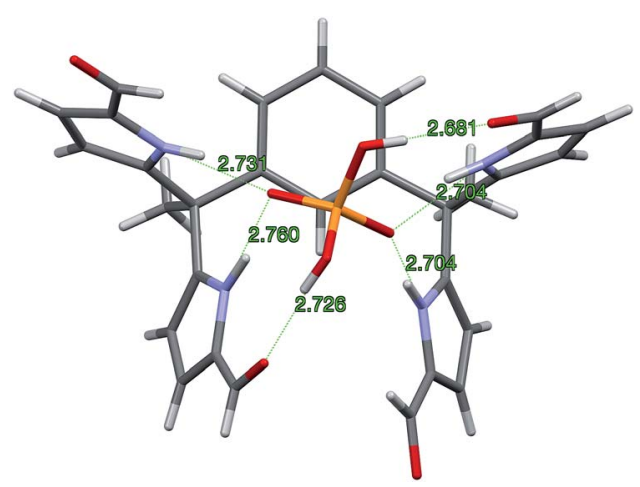

Fig. 4 Single crystal structure of the $1: 1$ complex $4 b \cdot \mathrm{H}_{2} \mathrm{PO}_{4}{ }^{-}$viewed from the top of the bound $\mathrm{H}_{2} \mathrm{PO}_{4}{ }^{-}$molecular ion. One $\mathrm{TBA}^{+}$counter cation is associated with each complex. It and a $\mathrm{CHCl}_{3}$ solvent molecule are omitted for clarity. 
associated with the hydrogen bonding between the formyl groups and the hydrogen atoms of $\mathrm{H}_{2} \mathrm{PO}_{4}{ }^{-}$are 2.681 and 2.726 $\AA$, respectively. Overall, derivative $4 \mathbf{b}$ stabilizes six hydrogen bonding interactions with the $\mathrm{H}_{2} \mathrm{PO}_{4}{ }^{-}$anion. Specifically, it acts as a four-fold donor via the pyrrolic $\mathrm{NH}$ protons and acts as a two-fold acceptor via the two formyl moieties.

Single crystals of complex $7 \mathbf{b} \cdot \mathrm{H}_{2} \mathrm{PO}_{4}{ }^{-}$were obtained by using $\mathrm{TBAH}_{2} \mathrm{PO}_{4}$ to solubilize receptor $7 \mathbf{b}$ in $\mathrm{CHCl}_{3}$ (by conversion to the corresponding dihydrogenphosphate complex) and then layering with $n$-pentane. The resulting structure is shown in Fig. 5. Although some analogy to that of 4b $\cdot \mathrm{H}_{2} \mathrm{PO}_{4}{ }^{-}$discussed above is seen as regard the diformyl DPMdihydrogenphosphate interactions, in $7 \mathbf{b} \cdot \mathrm{H}_{2} \mathrm{PO}_{4}{ }^{-}$, the third diformyl-DPM of $\mathbf{7 b}$ is too distant to interact well with the bound $\mathrm{H}_{2} \mathrm{PO}_{4}{ }^{-}$anion. It thus interacts in an intermolecular sense with a dihydrogenphosphate anion bound to a second receptor. The result is a dimeric complex with overall $2: 2$ stoichiometry. The four pyrrole NH-to-deprotonated phosphate oxygen $\mathrm{N}-\mathrm{H} \cdots \mathrm{O}$ distances range from 2.730 to $2.827 \AA$. The intermolecular hydrogen bond that is presumed to play a role in stabilizing the $2: 2$ complex is characterized by an $\mathrm{O}-\mathrm{H} \cdots \mathrm{O}$ distance of $2.598 \AA$.

Based on the binding mode observed in the solid state, we considered it likely that anion $-\pi$ interactions, as well as pyrrole $\mathrm{NH}$-anion hydrogen bonding interactions contribute to anion binding. To explore this possibility, the effect of adding $\mathrm{TBAH}_{2} \mathrm{PO}_{4}$ to the most soluble receptor of the present series, namely the meta-derivative $\mathbf{4} \mathbf{b}$, was investigated by ${ }^{1} \mathrm{H}$ NMR spectroscopy (Fig. 6). Upon addition of one molar equivalent of $\mathrm{TBAH}_{2} \mathrm{PO}_{4}$ to a $\mathrm{CDCl}_{3}$ solution of $\mathbf{4 b}$, discernible shifts in the proton resonances of $\mathbf{4 b}$ were observed ( $c f$. Table 2 ). Of particular note were the $0.6 \mathrm{ppm}$ upfield shifts seen for the proton signals of the linking benzene ring. Similar ${ }^{1} \mathrm{H}$ NMR spectroscopic studies of $\mathbf{5 b}$ carried out in $\mathrm{CDCl}_{3}, \mathbf{7 b}$ in a more competitive solvent mixture, $\mathrm{CDCl}_{3}: \mathrm{DMSO}_{6}(8: 1)$, likewise revealed upfield shifts in the intervening benzene resonances

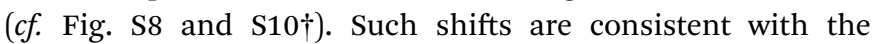
decrease in the deshielding effect of the intervening aromatic ring current as seen in previous studies of $\alpha, \alpha, \alpha, \alpha-m e s o-$

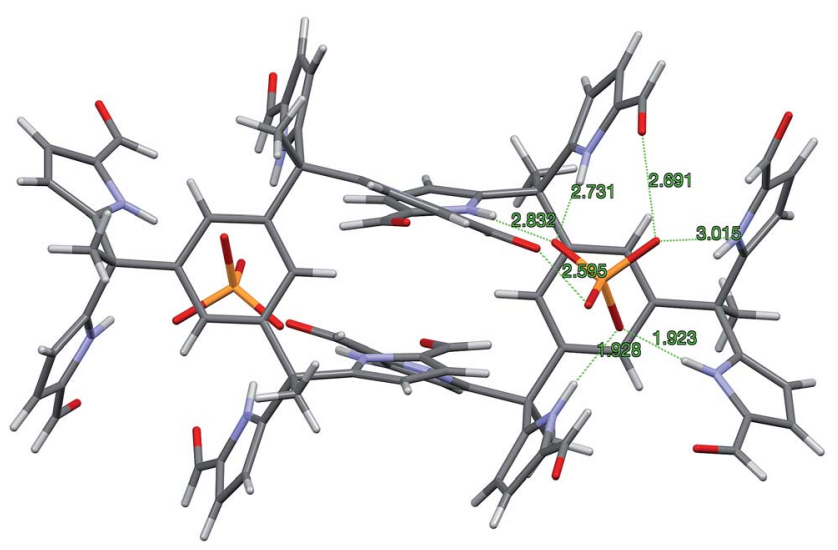

Fig. 5 Single crystal structure of the $2: 2$ complex $\left[7 b \cdot \mathrm{H}_{2} \mathrm{PO}_{4}{ }^{-}\right]_{2}$. One $\mathrm{TBA}^{+}$counter cation per $\mathrm{H}_{2} \mathrm{PO}_{4}{ }^{-}$and 1.5 molecules of $\mathrm{CHCl}_{3}$ per $7 \mathrm{~b}$ have been omitted for clarity.



Fig. 6 Partial ${ }^{1} \mathrm{H}$ NMR spectra of receptor $4 \mathrm{~b}$ before (bottom) and after (top) addition of one molar equivalent of $\mathrm{TBAH}_{2} \mathrm{PO}_{4}$ in $\mathrm{CDCl}_{3}$. Dashed lines show the changes in the chemical shifts of selected proton signals ascribable to receptor $4 b$.

Table 2 Summary of chemical shifts of selected proton resonances of $4 \mathrm{~b}$ before and after addition of one molar equivalent of $\mathrm{TBAH}_{2} \mathrm{PO}_{4}$ in $\mathrm{CDCl}_{3}$

\begin{tabular}{cccc} 
& \multicolumn{2}{c}{$\delta(\mathrm{ppm})$} & \\
\cline { 2 - 3 } $\mathrm{H}$ & $\mathbf{4 b}^{a}$ & $\mathbf{4 b} \cdot \mathrm{H}_{2} \mathrm{PO}_{4}^{-b}$ & $\Delta \delta$ \\
\hline $\mathrm{H}^{1}$ & 7.25 & 7.10 & -0.15 \\
$\mathrm{H}^{2}$ & 7.10 & 6.70 & -0.40 \\
$\mathrm{H}^{3}$ & 6.90 & 6.30 & -0.60 \\
$\mathrm{H}^{4}$ & 6.80 & 6.85 & +0.05 \\
$\mathrm{H}^{5}$ & 6.00 & 6.30 & +0.30
\end{tabular}

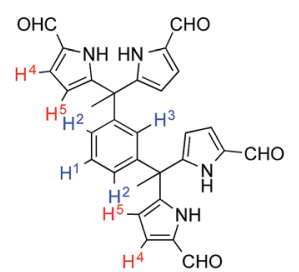

${ }^{a}$ The solution of $\mathbf{4 b}$ was prepared from diffraction grade single crystals of $\mathbf{4 b}$, which contained two DMF molecules of crystallization per equivalent of receptor. ${ }^{b}$ Obtained by treating with the $\mathrm{TBA}^{+}$salt of $\mathrm{H}_{2} \mathrm{PO}_{4}^{-}$; see text for details.

tetraaryl-C[4]P derivatives by Ballester and co-workers. ${ }^{31}$ However, as noted by a reviewer, such an observation is not sufficient to confirm or rule out the presence of an anion- $\pi$ interaction. Intuitively, the interaction of anion $\mathrm{H}_{2} \mathrm{PO}_{4}{ }^{-}$with the electron-rich intervening benzene ring of $\mathbf{4} \mathbf{b}$ is expected to be repulsive, thus destabilizing the overall binding event. However, Deyà ${ }^{32}$ has suggested that the polarization of a $\pi$ electron system by an anion induces a dipole moment that may provide a contribution to the anion-receptor interaction. In the case of the present system, further studies will be necessary to determine whether anion- $\pi$ interactions (if any) are playing a substantial role in mediating the observed anion recognition behaviour.

Receptor $\mathbf{7 b}$ proved even less soluble in neat, non-hydrogen bonding solvents, such as $\mathrm{CHCl}_{3}$, than its congeners $\mathbf{3 b} \mathbf{- 5} \mathbf{b}$. This made it impossible to carry out binding studies that were directly comparable to those reported earlier. ${ }^{24}$ However, in analogy to what was seen in the case of these other receptors, it was found that the solubility of $\mathbf{7 b}$ increased upon the addition of $\mathrm{TBAH}_{2} \mathrm{PO}_{4}$. Dilute solutions of $7 \mathbf{b} \cdot \mathrm{H}_{2} \mathrm{PO}_{4}{ }^{-}$in $\mathrm{CHCl}_{3}$ could thus be prepared by mixing single crystals of $7 \mathbf{b}$ with $\mathrm{ca} .2 .75$ molar equivalents of $\mathrm{TBAH}_{2} \mathrm{PO}_{4}$. The UV-Vis spectrum of this solution was characterized by features similar to those seen in the reported spectrum of $3 \mathbf{b} \cdot \mathrm{H}_{2} \mathrm{PO}_{4}{ }^{-}$at analogous concentrations. Thus, the observed spectral features were ascribed to the complex $7 \mathbf{b} \cdot \mathrm{H}_{2} \mathrm{PO}_{4}{ }^{-}$. When the $\mathrm{CHCl}_{3}$ solution made up from 7b and $\mathrm{TBAH}_{2} \mathrm{PO}_{4}$ was titrated with $\mathrm{CH}_{3} \mathrm{OH}$, spectral changes and isosbestic behaviour were observed. On this basis, we 

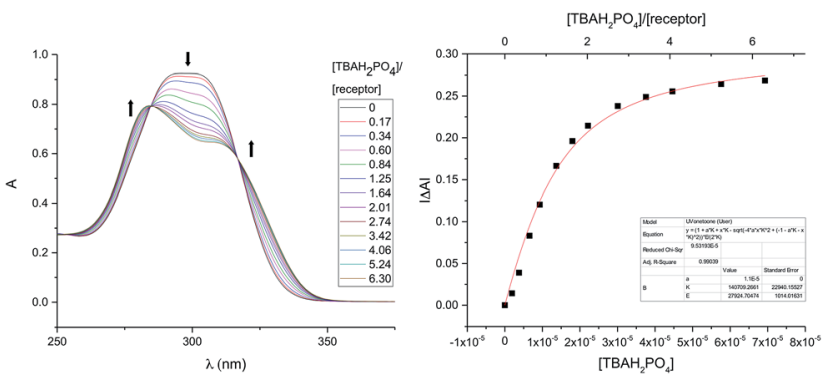

Fig. 7 Left: Stacked UV-Vis spectra for titration of $7 \mathrm{~b}\left(1.1 \times 10^{-5} \mathrm{M}\right)$ with $\mathrm{TBAH}_{2} \mathrm{PO}_{4}\left(2.9 \times 10^{-4} \mathrm{M}\right)$ in $\mathrm{CHCl}_{3}$ containing $3 \%(\mathrm{v} / \mathrm{v}) \mathrm{CH}_{3} \mathrm{OH}$ Right: Binding curve fitting plotted from titration data at $302 \mathrm{~nm} . K_{\mathrm{a}}=$ $(1.4 \pm 0.2) \times 10^{5} \mathrm{M}^{-1}$.

conclude that the $\mathrm{H}_{2} \mathrm{PO}_{4}{ }^{-}$affinity of $7 \mathbf{b}$ decreases in the presence of increasing quantities of $\mathrm{CH}_{3} \mathrm{OH}$ (Fig. S15†). However, it was also apparent that large quantities of methanol were required to disrupt the complex completely. It was thus decided that a solution of $3 \%(\mathrm{v} / \mathrm{v}) \mathrm{CH}_{3} \mathrm{OH}$ in $\mathrm{CHCl}_{3}$ would provide a good balance between solubility and binding affinity and allow for quantitative analyses.

In a first set of experiments, an $11 \mu \mathrm{M}$ solution of $7 \mathbf{b}$ in $3 \%(\mathrm{v} /$ v) $\mathrm{CH}_{3} \mathrm{OH}$ in $\mathrm{CHCl}_{3}$ was prepared and then subjected to titration with $\mathrm{TBAH}_{2} \mathrm{PO}_{4}$ ( $c f$. Fig. 7). The induced spectral changes were then fit to a $1: 1$ binding profile and used to calculate the binding constant corresponding to $\mathrm{H}_{2} \mathrm{PO}_{4}{ }^{-}$binding in accord with the methods described previously. ${ }^{24}$ Similar UV-Vis titrations were carried out with a series of anions in the form of their respective TBA salts. It was found that titration with either the $\mathrm{H}_{2} \mathrm{PO}_{4}{ }^{-}$or $\mathrm{HP}_{2} \mathrm{O}_{7}{ }^{3-}$ anions gave rise to significant spectral changes with saturation behaviour being observed in the presence of fewer than ten molar equivalents of these two anions. On the other hand, no discernable spectral changes were seen upon titration with $\mathrm{HSO}_{4}{ }^{-}, \mathrm{Cl}^{-}$, or $\mathrm{NO}_{3}{ }^{-}$.

In the initial studies of $\mathbf{3 b} \mathbf{b} \mathbf{5} \mathbf{b}, \mathrm{CHCl}_{3}$ was used as the solvent. To allow for a comparison between the original tetrakis- $(1 \mathrm{H}$ pyrrole-2-carbaldehyde) anion receptors and the newer and hexakis analogue $\mathbf{7 b}$, compound $\mathbf{3 b}$ was subject to titration with $\mathrm{H}_{2} \mathrm{PO}_{4}^{-}$in $3 \%(\mathrm{v} / \mathrm{v}) \mathrm{CH}_{3} \mathrm{OH}-\mathrm{CHCl}_{3}$. The results from this comparison are summarised in Table 3 . Briefly, $\mathbf{7 b}$ is characterized by a $c a$. 2 orders of magnitude higher dihydrogenphosphate anion affinity. This increase is in accord with the design expectations underlying $\mathbf{7 b}$, namely that the presence of a third DPM

Table 3 Summary of calculated binding affinities, $K_{a}\left(M^{-1}\right)$ as determined by UV-Vis spectroscopy in two separate solvent systems ${ }^{a}$

\begin{tabular}{llll}
\hline Anions $^{a}$ & $\mathbf{3} \mathbf{b}^{b}$ & $\mathbf{3 \mathbf { b } ^ { c }}$ & $\mathbf{7 \mathbf { b } ^ { c }}$ \\
\hline $\mathrm{H}_{2} \mathrm{PO}_{4}{ }^{-}$ & $(8 \pm 2) \times 10^{6}$ & $(2.1 \pm 0.3) \times 10^{3}$ & $(1.4 \pm 0.2) \times 10^{5}$ \\
$\mathrm{HP}_{2} \mathrm{O}_{7}{ }^{3-}$ & $(1.4 \pm 0.1) \times 10^{5}$ & $(3.8 \pm 0.6) \times 10^{3}$ & $(3.6 \pm 0.2) \times 10^{4}$ \\
$\mathrm{HSO}_{4}{ }^{-}$ & $(4.1 \pm 0.2) \times 10^{3}$ & nd & nd \\
$\mathrm{NO}_{3}{ }^{-}$ & nd & nd & nd \\
$\mathrm{Cl}^{-}$ & nd & nd & nd
\end{tabular}

${ }^{a}$ The anions were studied as their $\mathrm{TBA}^{+}$salts. ${ }^{b}$ In $\mathrm{CHCl}_{3}$; data from ref. 24. ${ }^{c}$ In $\mathrm{CHCl}_{3}$ containing $3 \%(\mathrm{v} / \mathrm{v}) \mathrm{CH}_{3} \mathrm{OH}$. subunit would force this system to adopt a preorganised conformation in a way that isn't possible for $\mathbf{3 b}$.

To exploit the binding characteristics of the present diformylDPM receptors for the purposes of anion sensing, analogue $\mathbf{6 b}$ was prepared. It incorporates a ferrocene spacer and was designed to perform as an electro-active analogue of the tetrakis $1 \mathrm{H}$-pyrrole2-carbaldehyde) receptors $\mathbf{3 b} \mathbf{b} \mathbf{5 b}$. This new derivative proved poorly soluble in typical organic solvents used for electrochemical studies (e.g., $\mathrm{CH}_{3} \mathrm{CN}$, DMF, $\mathrm{CH}_{2} \mathrm{Cl}_{2}$ ). However, as above, an increase in its solubility was seen upon the addition of $\mathrm{TBAH}_{2} \mathrm{PO}_{4}$. This was seen as a "useful property"33 that could be used to obtain insights into the $\mathrm{H}_{2} \mathrm{PO}_{4}{ }^{-}$binding events under conditions of electrochemical analysis. It was found, for instance, that initial turbid mixtures of free receptor $\mathbf{6 b}$ in $\mathrm{CH}_{3} \mathrm{CN}$ containing $10 \%(\mathrm{v} / \mathrm{v})$ DMF give rise to a quasi-reversible cyclic voltammogram (CV) (black line in Fig. 8). The oxidation wave for $\mathbf{6 b}$ becomes increasingly irreversible as the relative concentration of $\mathrm{TBAH}_{2}-$ $\mathrm{PO}_{4}$ increases. Eventually, the $\mathrm{CV}$ becomes characterized by a relatively intense anodic peak and a near-absence of a corresponding cathodic feature.

The observed increase in the anodic peak current is ascribed to the increase in the concentration of $\mathbf{6 b}$ (both free and complexed) that occurs as the titration runs its course. Since the $\mathbf{6 b}$ is not completely soluble in the solvent mixture in the absence of $\mathrm{H}_{2} \mathrm{PO}_{4}{ }^{-}$, the concentration of free $\mathbf{6 b}$ in the titration mixture should be constant up until the point where all traces of solid $\mathbf{6 b}$ are dissolved, presumably by conversion to the corresponding dihydrogenphosphate complex, $\mathbf{6 b} \cdot \mathrm{H}_{2} \mathrm{PO}_{4}{ }^{-}$. To the extent such a supposition is correct, it would account for the observed increase in the peak current, which could be attributed directly to the formation of the readily oxidizable species, $6 \mathbf{b} \cdot \mathrm{H}_{2} \mathrm{PO}_{4}{ }^{-}$. When the increase in the anodic peak current is plotted against the added $\mathrm{H}_{2} \mathrm{PO}_{4}{ }^{-}$concentration, a binding isotherm could be

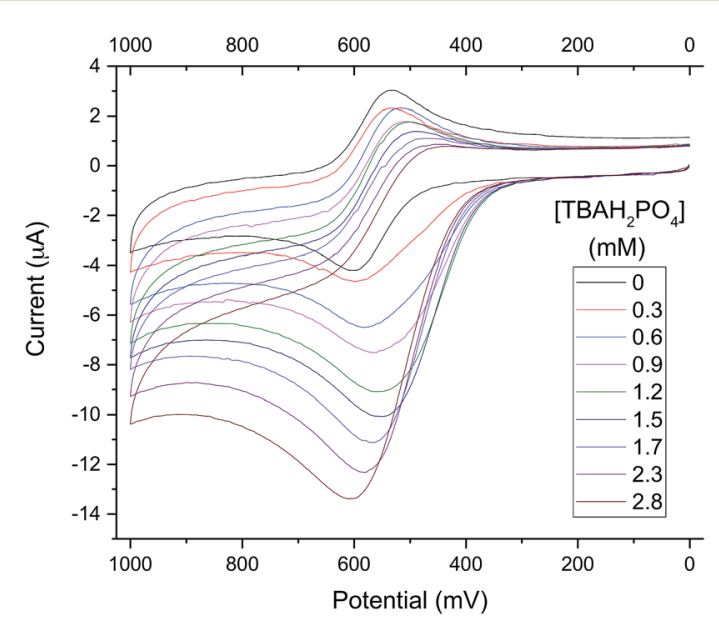

Fig. 8 Stacked cyclic voltammogram of $6 \mathrm{~b}$ in $\mathrm{CH}_{3} \mathrm{CN}$ containing $10 \%$ $(\mathrm{v} / \mathrm{v})$ DMF. The initial turbid mixture of $6 \mathrm{~b}$ contained a quantity of material sufficient to produce a $1.0 \mathrm{mM}$ solution once completely dissolved. This mixture was titrated with $\mathrm{TBAH}_{2} \mathrm{PO}_{4}$ until the $\mathrm{TBAH}_{2}$ $\mathrm{PO}_{4}$ concentration reached $2.8 \mathrm{mM}$. TBAPF $6(0.1 \mathrm{M})$ was used as the supporting electrolyte. Glassy carbon was used as the working electrode, a Pt wire as the counter electrode, and a $\mathrm{Ag} / \mathrm{AgCl}$ couple as the reference electrode. 


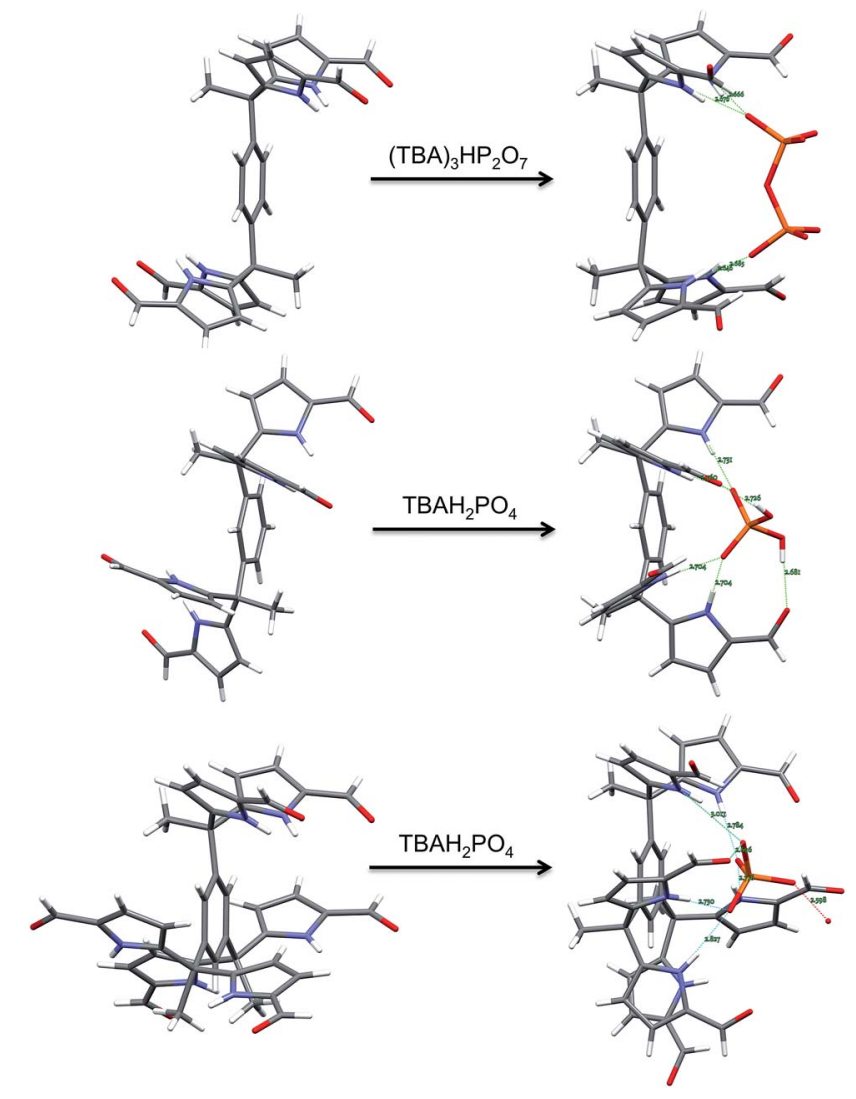

Fig. 9 Views of the single crystal structures of $3 b, 4 b$, and $7 b$ in the absence and presence of bound phosphate derivatives.

obtained ( $c f$. Fig. S20 $\dagger$ ) from which an approximate $\mathrm{H}_{2} \mathrm{PO}_{4}{ }^{-}$ affinity, $(1.0 \pm 0.1) \times 10^{3} \mathrm{M}^{-1}$, could be calculated $(c f$. Table ESI$1 \dagger)$. The loss in reduction signal intensity is believed to reflect the strong interaction between the oxidized ferrocenium receptor $\left(6 \mathbf{b}^{+}\right)$and $\mathrm{H}_{2} \mathrm{PO}_{4}{ }^{-}$.

\section{Conclusions}

In summary, we have extended the tetrakis $1 H$-pyrrole-2-carbaldehyde) receptor family to include a new electroactive derivative, 6b, incorporating a ferrocene linker. Also reported here is a hexaformyl trisDPM derivative, $7 \mathbf{b}$. The anion binding properties of these new systems were studied by monitoring the increase in solubility electrochemically, through high-resolution mass spectrometric analyses, $1 \mathrm{D}{ }^{1} \mathrm{H}$ NMR and 2D DOSY spectroscopic experiments, single crystal X-ray diffraction analyses, and UV-Vis spectroscopic titrations. Conformational switching from trans-like conformations as seen in the free tetrakis- $(\mathbf{3 b}, \mathbf{4 b})$ and hexakis- (7b) (1H-pyrrole-2-carbaldehyde) receptors to the corresponding cis-like conformations upon interacting with phosphate derivatives was revealed by X-ray diffraction analyses in the solid state (Fig. 9). In mixed methanol-chloroform solution, the new hexakis-carbaldehyde derivative $7 \mathbf{b}$ was found to exhibit an affinity for $\mathrm{H}_{2} \mathrm{PO}_{4}{ }^{-}$that is roughly $100 \times$ higher than that displayed by the tetrakis analogue $\mathbf{3 b}$. This increase in binding affinity is rationalized in terms of a receptor design that overcomes in part the conformational penalty that needs to be paid in order to achieve substrate binding. As such, the present findings provide experimental insights that might prove useful in the design of anion receptors based on rather simple binding motifs, such as pyrroles and dipyrromethane subunits.

\section{Acknowledgements}

This work was supported by the Office of Basic Energy Sciences, U.S. Department of Energy (DOE) (Grant DE-FG02-01ER15186 to J. L. S.).

\section{Notes and references}

1 J. L. Sessler, P. A. Gale and W.-S. Cho, Anion Receptor Chemistry, Royal Society of Chemistry, Cambridge, 2006.

2 J. H. Ryther and W. M. Dunstan, Science, 1971, 171, 10081013.

3 A. K. H. Hirsch, F. R. Fischer and F. Diederich, Angew. Chem., Int. Ed., 2007, 46, 338-352.

4 Y. Zhang, E. Desmidt, A. Van Looveren, L. Pinoy, B. Meesschaert and B. Van Der Bruggen, Environ. Sci. Technol., 2013, 47, 5888-5895.

5 E. A. Katayev, Y. A. Ustynyuk and J. L. Sessler, Coord. Chem. Rev., 2006, 250, 3004-3037.

6 A. E. Hargrove, S. Nieto, T. Zhang, J. L. Sessler and E. V. Anslyn, Chem. Rev., 2011, 111, 6603-6782.

7 J. W. Steed, D. R. Turner and K. Wallace, Core Concepts in Supramolecular Chemistry and Nanochemistry, John Wiley, Hoboken, NJ, 2007.

8 P. A. Gale, Coord. Chem. Rev., 2003, 240, 191-221.

9 S. L. Tobey and E. V. Anslyn, J. Am. Chem. Soc., 2003, 125, 14807-14815.

10 J. L. Sessler, M. J. Cyr, V. Lynch, E. McGhee and J. A. Ibers, J. Am. Chem. Soc., 1990, 112, 2810-2813.

11 G. Cavallo, P. Metrangolo, T. Pilati, G. Resnati, M. Sansotera and G. Terraneo, Chem. Soc. Rev., 2010, 39, 3772-3783.

12 P. Gamez, T. J. Mooibroek, S. J. Teat and J. Reedijk, Acc. Chem. Res., 2007, 40, 435-444.

13 G. A. Jeffrey, An Introduction to Hydrogen Bonding, Oxford University Press, Oxford, 1997.

14 Note: Under certain conditions, deprotonation, rather than anion binding, has been observed with pyrrolic receptors.

15 S. Camiolo, P. A. Gale, M. B. Hursthouse, M. E. Light and A. J. Shi, Chem. Commun., 2002, 3, 758-759.

16 B. L. Iverson, K. Shreder, V. Král and J. L. Sessler, J. Am. Chem. Soc., 1993, 115, 11022-11023.

17 P. A. Gale, J. L. Sessler, V. Král and V. Lynch, J. Am. Chem. Soc., 1996, 118, 5140-5141.

18 A. Baeyer, Ber. Dtsch. Chem. Ges., 1886, 19, 2184-2185.

19 R. Custelcean, L. H. Delmau, B. A. Moyer, J. L. Sessler, W.-S. Cho, D. Gross, G. W. Bates, S. J. Brooks, M. E. Light and P. A. Gale, Angew. Chem., Int. Ed., 2005, 44, 2537-2542.

20 D. E. Gross, F. P. Schmidtchen, W. Antonius, P. A. Gale, V. M. Lynch and J. L. Sessler, Chem.-Eur. J., 2008, 14, 7822-7827. 
21 W.-S. Cho, PhD Dissertation, The University of Texas at Austin, 2005.

22 J. L. Sessler, W.-S. Cho, S. P. Dudek, L. Hicks, V. M. Lynch and M. T. Huggins, J. Porphyrins Phthalocyanines, 2003, 07, 97-104.

23 J. L. Sessler, S. Camiolo and P. A. Gale, Coord. Chem. Rev., 2003, 240, 17-55.

24 M. K. Deliomeroglu, V. M. Lynch and J. L. Sessler, Chem. Commun., 2014, 50, 11863-11866.

25 R. Neufeld and D. Stalke, Chem. Sci., 2015, 6, 3354-3364.

26 R. Custelcean, Chem. Soc. Rev., 2010, 39, 3675-3685.

27 N. L. Bill, D.-S. Kim, S. K. Kim, J. S. Park, V. M. Lynch, N. J. Young, B. P. Hay, Y. Yang, E. V. Anslyn and J. L. Sessler, Supramol. Chem., 2012, 24, 72-76.
28 J. Cai, B. P. Hay, N. J. Young, X. Yang and J. L. Sessler, Chem. Sci., 2013, 4, 1560-1567.

29 V. Král, H. Furuta, K. Shreder, V. Lynch and J. L. Sessler, J. Am. Chem. Soc., 1996, 118, 1595-1607.

30 M. Wei, B. Wu, L. Zhao, H. Zhang, S. Li, Y. Zhao and X.-J. Yang, Org. Biomol. Chem., 2012, 10, 8758-8761.

31 G. Gil-Ramírez, E. C. Escudero-Adán, J. Benet-Buchholz and P. Ballester, Angew. Chem., Int. Ed., 2008, 47, 4114-4118.

32 D. Quiñonero, A. Frontera and P. M. Deyà, in Anion Coordination Chemistry, ed. K. Bowman-James, A. Bianchi and E. García-Espana, Wiley-VCH Verlag \& Co. KGaA, Weinheim, 2012, ch. 6, pp. 321-362.

33 K. A. Connors, Binding constants: The Measurement of Molecular Complex Stability, Wiley, New York, 1987. 